\title{
A SMALL WASTEWATER TREATMENT STATION BUILT WITH PVC AND ASSOCIATED TO BIOGAS POWER GENERATOR
}

\author{
W. Q. Lamas ${ }^{\mathrm{a}, \mathrm{b}}$, \\ J. L. Silveira ${ }^{a}$, \\ and G. E. O. Giacaglia \\ ${ }^{\text {a }}$ Universidade Estadual Paulista \\ Faculdade de Engenharia \\ Campus de Guaratinguetá \\ Departamento de Energia \\ Av. Dr. Ariberto Pereira da Cunha, 333 - \\ Pedregulho \\ 12516-410, Guaratinguetá, São Paulo, Brasil. \\ ${ }^{\mathrm{b}}$ Universidade de Taubaté \\ Departamento de Engenharia Mecânica \\ Programa de Mestrado em Engenharia \\ Mecânica \\ Rua Daniel Danelli, s/n - Jd. Morumbi \\ 12060-440, Taubaté, São Paulo, Brasil. \\ lamaswq@gmail.com
}

\section{ABSTRACT}

This work describes features related to a small wastewater treatment station installed at Sao Paulo State University, Faculty of Engineering, and Campus of Guaratingueta. An introduction about this topic is discussed focusing on its importance for environment (greenhouse effect) and for sewage treatment. Several works related to this topic are discussed. Following, a general plant is described. Concluding, some articular aspects are discussed such as CDO and BDO removal. Also, a comparison between real measured values and values recommend by Brazilian environmental legislation is discussed.

Keywords: biochemical demand of oxygen, biogas production, chemical demand of oxygen, power generation, sewerage, wastewater treatment.

\section{NOMENCLATURE}

BOD biochemical demand of oxygen

COD chemical demand of oxygen

$c_{p}$ fluid specific heat at constant pressure, $\mathrm{J} /(\mathrm{kg} . \mathrm{K})$

E energy, $\mathrm{kW}$

LHV low heat value, $\mathrm{kJ} / \mathrm{kg}$

$\dot{\mathrm{m}}$ mass flow, $\mathrm{kg} / \mathrm{s}$

$\mathrm{T}$ average fluid temperature, $\mathrm{K}$

\section{Greek symbols}

$\Delta \mathrm{T} \quad$ variation of temperature, $\mathrm{K}$

$\eta \quad$ efficiency, $\%$

\section{Subscripts}

bg biogas

c combustion

eg exhaust gases

$f$ fuel

ge generation of energy

ghw generation of hot water

gl global

he heat exchanger

$\mathrm{p} \quad$ production of electricity

w water

\section{INTRODUCTION}

World has been affected by several energy crises, resulting in a search for alternative solutions to large and small size electromechanical and thermal energy generators, improving additionally the rational use of energy generated by traditional plants. Environment protection has also been one of the main goals in these researches.

This new focus on alternative energy sources (Beduschi et al., 1983) provided new modelling techniques, more accuracy for new power systems, allowing for a more rigorous and discerning technical-economical analysis. Among these techniques it is worth mentioning exergoeconomic and thermoeconomic analysis models appearing in the scenario, used as a very powerful tool for energy systems optimisation (Silveira, 1998).

Methane is the main component of biogas generated from anaerobic wastewater treatment and it is about 21 times more harmful that carbonic gas related relate to the greenhouse effect (Jordao and Alem Sobrinho, 2004). This characteristic shows that the biogas produced by sewage treatment is an interesting contribution to renewable energy generation and environmental sanitation.

Focusing on this issue, a small wastewater treatment station (SWTS), built at Sao Paulo State 
University - UNESP (Fig. 1 and Fig. 2), was designed for use of biogas in power energy generation through an improved power generation system. The system comprises a water wheel connected to a twin aerobic bioreactor producing energy and injecting air into the reactors improving the final treatment. It is also possible to use a part of treated as a biofertilizer in near green areas.

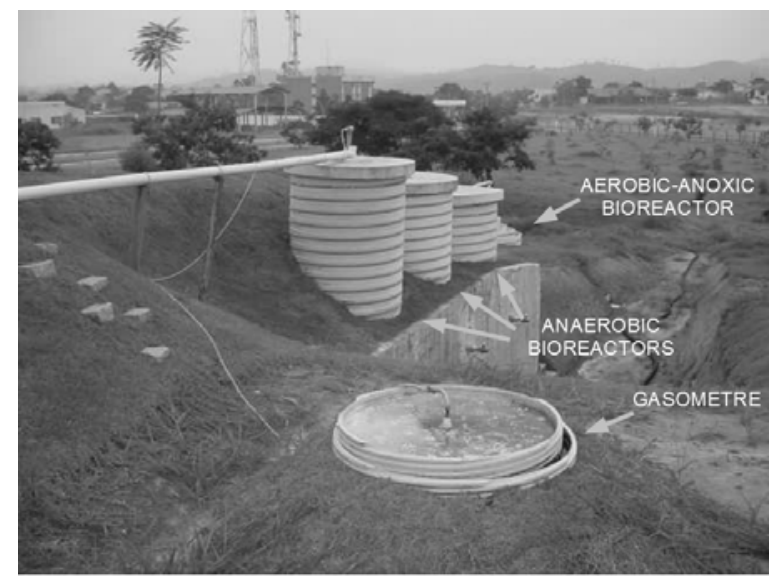

Figure 1. Small wastewater treatment station at UNESP (back view).

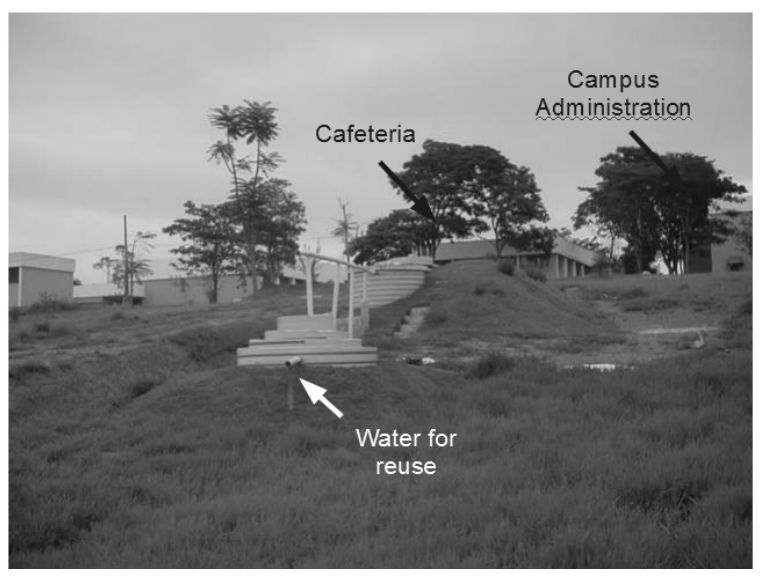

Figure 2. Small wastewater treatment station at UNESP (front view).

\section{Related Works}

Beduschi et al. (1983) discuss about economical feasibility of bioreactor estimating the construction cost of a bioreactor system capable to produce $10 \mathrm{~m} 3$ of biogas and 500 litres of fertilizer per day. It is also possible to approach values for biofertilizer and biogas when compared to traditional waste water treatment plants such as $0.017 \%$ for biofertilizer and $0.05 \%$ for biogas.

Silveira (1998) studied a thermoeconomic optimisation method for use in energy systems. Economics characteristics are associated to exergetic techniques to develop such optimization, which was adopted to develop a methodology to analyse small waste water treatment plants through their economical and exergetical characteristics.

A sort of anaerobic and aerobic bioreactors characteristics were obtained by Oliveira and Forresti, (2004); Oliveira (2001); Jordao and Alem Sobrinho (2004); Guardabassi and Pires (2006); and Martins et al. (2006), such as typical values for Low Power Value of urban residues, biomass, and biogas, waste water treatment condition in Brazil, comparison between different bioreactors types, power generation and biogas production features, among others.

\section{MATERIAL AND METHODS}

\section{Plant Description}

Biogas is produced in three anaerobic bioreactors. This biogas is transferred to a gasometre maintaining a pressure previously established to be fed an air cooled internal combustion engine, which forms the generation system. Figure 3 shows the small waste water treatment station associated to biogas self-generation and to water wheel.

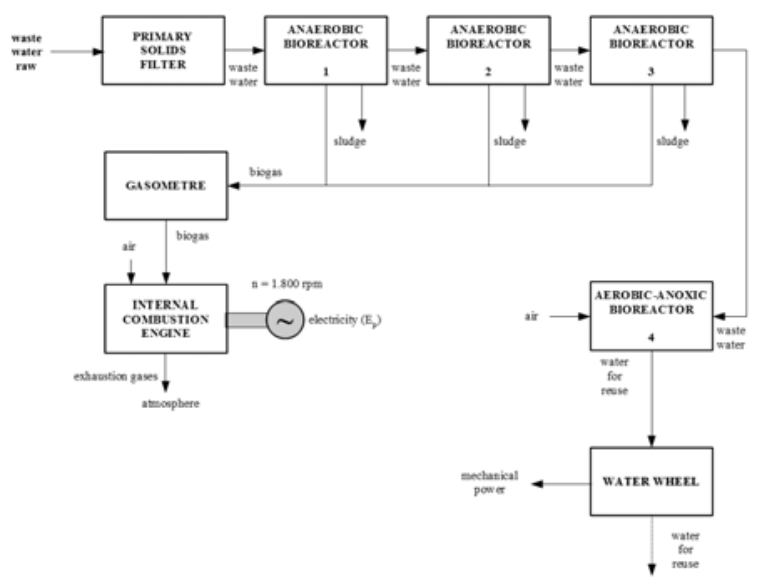

Figure 3. Small wastewater treatment station block diagram.

Wastewater from administration and cafeteria buildings (Fig. 2) enters through primary solids filter. This preliminary treatment eliminates the rudest solids, such as fat blocks.

Waste water follows through three up-flow sludge blanket anaerobic bioreactors, which separate solid residues (sludge), biogas, and wastewater (preliminary treatment) through a helical phase flow. In this stage, part of the sludge is removed and used as biofertilizer. Another part is maintained because micro-organisms present in there, predominantly of Methanosaeta gender (Oliveira e Forresti, 2004), digest organic material present in sludge to produce biogas. This biogas is transferred to a gasometre, where it is stored at an appropriated pressure for engine fiding, responsible for the generation of sufficient power energy to maintain associated small 
energy systems such as a control room, illumination, a pump etc.

Wastewater flows until a fourth bioreactor (aerobic-anoxic), where aerobic micro-organisms digest any organic material that was not digested by anaerobic organisms, besides transforming amoniacal nitrogen in nitrate. Anoxic micro-organisms transform nitrate in gaseous nitrogen and remove part of phosphorous in sludge bacterial biomass form. At that stage, treated water falls on a water wheel and generates mechanical power as well as air for aerobic bacteria treatment. This reusable water may be used in green areas ferti-irrigation.

\section{Power Generation}

Power generation system is constituted by a market available small motor-generator set, designed to use diesel as fuel and it is necessary to be converted for biogas.

This motor-generator set had been chosen after an engine selection procedure that is explained in section "Engine Selection". Fig. 4 shows this motor.
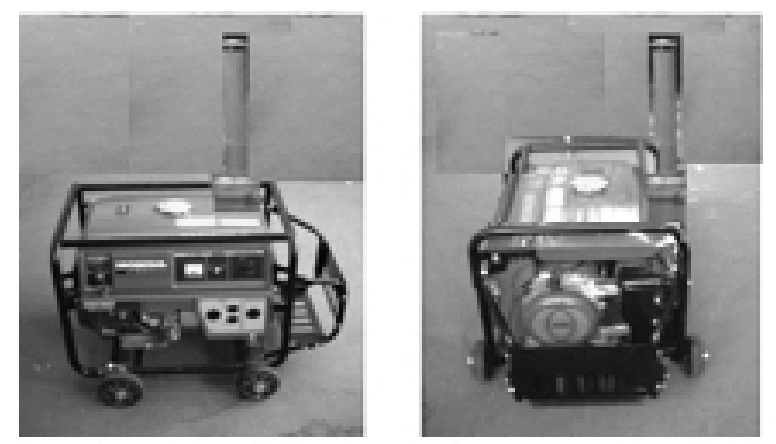

Figure 4. ICE converted for the of biogas.

\section{Engine Selection}

The selection of the engine has to be considered very carefully because the range of efficiency is very wide. Several factors should be taken in account.

First of all, there are three main categories of engines which possibly could be used; Otto engines running with gasoline or diesel, or diesel engines. By using an engine with diesel as fuel, the problem will occur that the engine needs a mixture of $20 \%$ diesel and $80 \%$ biogas to run without problems. Also, as diesel engines do not have spark plugs, pressure has to be applied to produce combustion. As biogas has a lower flaming point than diesel and the behaviour of biogas is more alike gasoline, an ignition device has to be used. Engines running with gasoline are much easier to transform to biogas because their chemical behaviour is more similar. In this study a large varieties of engines with powers between 3-6 kW were considered and compared.

Two engines, one diesel and one gasoline, with good efficiencies were selected and an economy analysis was applied to see the payback efficiency. In the case of this study, as the plant is just a pilot project, also very small engines had to be chosen. For a larger plant additional facts should be considered, such as pressure and the efficiency and shape of the heat exchangers.

The selection of an engine from different manufacturers has been made showing the best systems in terms of energy efficiency. We had to make a definite choice of an engine for each case, normally on basis of economy, the main concern of the project. The costs evaluations and investments necessary for the motors served as a basis for this selection. The main factor for the selection of the motor was the pay-back of the total investment and the efficiency.

For each case we selected the engine representing the shortest time of investment refunds, although all selected motors satisfy the required mechanical, thermal and electrical conditions of the processes. The global efficiency of the systems under analysis does not determine the final selection of the engine, but contributes to the economical efficiency or operational level.

In this work, a sort of assumptions have been considered, such as: specific heat of exhaust gases $(1.094 \mathrm{~kJ} / \mathrm{kg} . \mathrm{K})$, specific heat of water in steam phase $(2.02 \mathrm{~kJ} / \mathrm{kg} . \mathrm{K})$, specific heat of water in liquid phase $(4.187 \mathrm{~kJ} / \mathrm{kg} . \mathrm{K})$, specific density of biogas $\left(0.7 \mathrm{~kg} / \mathrm{m}^{3}\right.$ for $60 \%$ of $\mathrm{CH}_{4}, 35 \%$ of $\mathrm{CO}_{2}$, and $5 \%$ of $\mathrm{N}_{2}$ ), specific density of air $\left(1.1614 \mathrm{~kg} / \mathrm{m}^{3}\right)$, specific density of gasoline $\left(0.72-0.76 \mathrm{~kg} / \mathrm{m}^{3}\right)$, low heat value of biogas $\left(20,935 \mathrm{~kJ} / \mathrm{m}^{3}\right)$, low heat value of gasoline $\left(34,856.8 \mathrm{~kJ} / \mathrm{m}^{3}\right)$, and low heat value of diesel $\left(38,348.7 \mathrm{~kJ} / \mathrm{m}^{3}\right)$. The LHV values for $\mathrm{CO}_{2}$ and $\mathrm{N}_{2}$ are zero in this case, because they do not contribute to the energy output.

The efficiency of an engine or a heat exchanger has been evaluated by taking the fuel efficiency and the amount of heated water. Equations (1) to (7) are used to obtain the global efficiency of the engine.

$$
\begin{gathered}
\mathrm{E}_{\mathrm{c}}=\dot{\mathrm{m}}_{\mathrm{eg}} \cdot \mathrm{cp}_{\mathrm{eg}} \cdot \Delta \mathrm{T}_{\mathrm{eg}} \\
\mathrm{E}_{\mathrm{w}}=\dot{\mathrm{m}}_{\mathrm{w}} \cdot \mathrm{cp}_{\mathrm{w}} \cdot \Delta \mathrm{T}_{\mathrm{w}} \\
\mathrm{E}_{\mathrm{f}}=\dot{\mathrm{m}}_{\mathrm{bg}} \cdot \mathrm{LHV}_{\mathrm{bg}} \\
\eta_{\mathrm{he}}=\frac{\mathrm{E}_{\mathrm{w}}}{\mathrm{E}_{\mathrm{c}}}=0.8 \\
\eta_{\mathrm{ge}}=\frac{\mathrm{E}_{\mathrm{P}}}{\mathrm{E}_{\mathrm{fl}}} \\
\eta_{\mathrm{ghw}}=\frac{\mathrm{E}_{\mathrm{w}}}{\mathrm{E}_{\mathrm{f}}}
\end{gathered}
$$




$$
\eta_{\mathrm{gl}}=\eta_{\mathrm{ge}}+\eta_{\mathrm{ghw}}
$$

The mass flow of exhaust gases is evaluated from the addition of mass flow of biogas used and mass flow of air. The air/biogas mass ratio the biogas combustion is one part of fuel and twelve parts of air.

Biogas consumed in combustion is higher than gasoline, because its LHV is lower than gasoline's LHV. So, it is possible to evaluate biogas demand to produce the same energy that gasoline produces, evaluating energy produced with gasoline. Tables 1 to 3 (Bohme, 2004) relate characteristics of engines evaluated and values obtained to produce energy with gasoline and its correspondence with biogas demand.

\section{$\mathrm{H}_{2} \mathrm{~S}$ Filter}

The biogas filtering system is intended for $\mathrm{H} 2 \mathrm{~S}$ removal, which is corrosive and emits an unpleasant odour, increases working life of ICE to be used in the power self-generation sub-system and the biogas unpleasant smell mitigation (Spinola, 2007).

This filtration is obtained with a filter composed by PVC pipes with oxide steel wool and fine powder as filtering materials for $\mathrm{H}_{2} \mathrm{~S}$ retention. Fig. 5 shows this filtration system through sequential filters and Fig. 6 shows this filter installed in mini-ETE's gasometre output.

After filter installation, composition analysis of biogas produced in mini-ETE was obtained by sampling biogas collected in points before and after filter connections. This composition analysis considered $\mathrm{O}_{2}, \mathrm{~N}_{2}, \mathrm{CO}_{2}, \mathrm{CH}_{4}$, and $\mathrm{H}_{2} \mathrm{~S}$ as biogas, not considering any other gas. Table 4 lists their percentage values.

Four weeks later, a new analysis for biogas composition was done in order to validate preliminary results, as shown in Table 5.
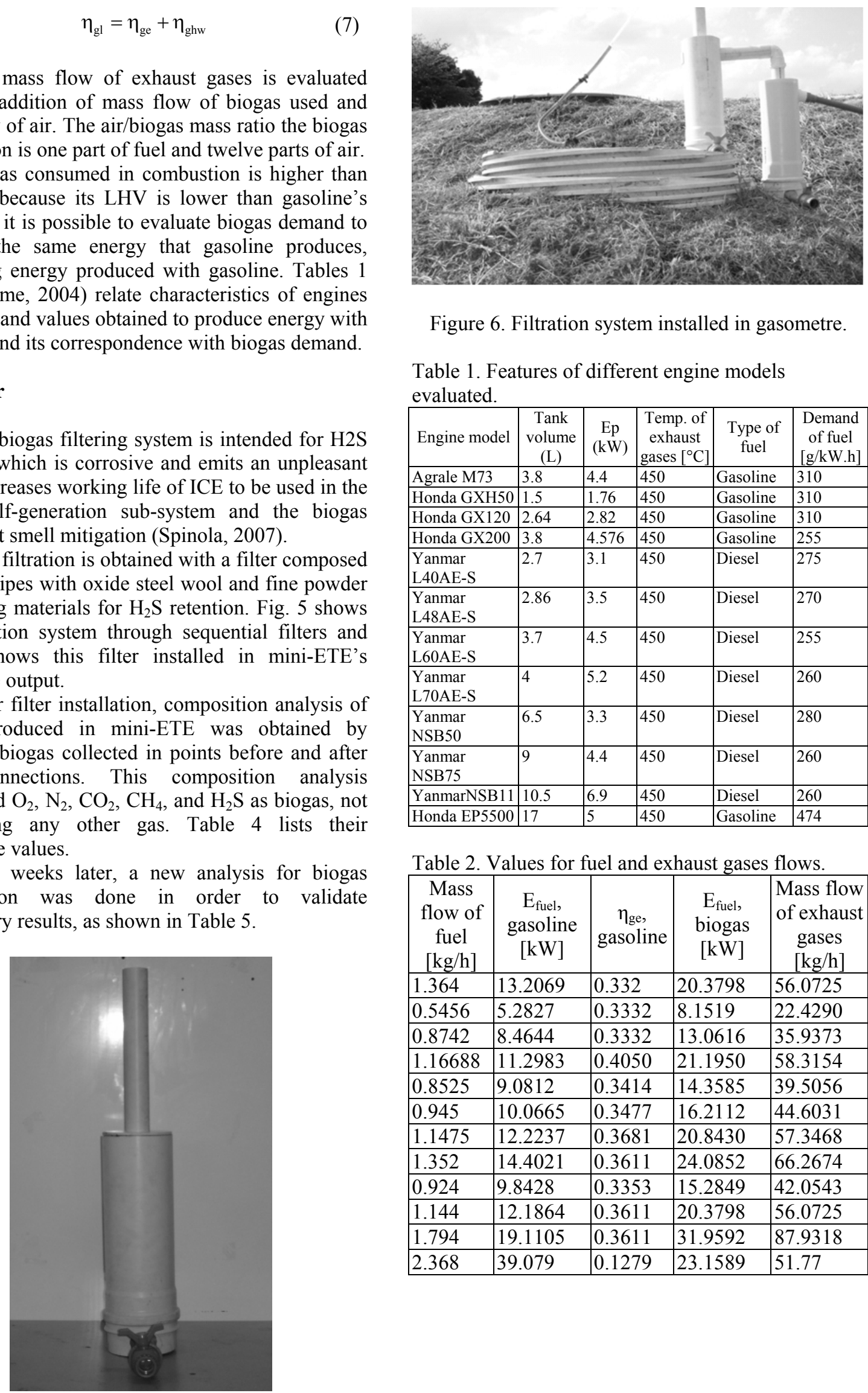

Figure 6. Filtration system installed in gasometre.

Table 1. Features of different engine models evaluated.

\begin{tabular}{|l|l|l|l|l|l|}
\hline Engine model & $\begin{array}{c}\text { Tank } \\
\text { volume } \\
(\mathrm{L})\end{array}$ & $\begin{array}{c}\text { Ep } \\
(\mathrm{kW})\end{array}$ & $\begin{array}{c}\text { Temp. of } \\
\text { exhaust } \\
\text { gases }\left[{ }^{\circ} \mathrm{C}\right]\end{array}$ & $\begin{array}{c}\text { Type of } \\
\text { fuel }\end{array}$ & $\begin{array}{c}\text { Demand } \\
\text { of fuel } \\
{[\mathrm{g} / \mathrm{kW} . \mathrm{h}]}\end{array}$ \\
\hline Agrale M73 & 3.8 & 4.4 & 450 & Gasoline & 310 \\
\hline Honda GXH50 & 1.5 & 1.76 & 450 & Gasoline & 310 \\
\hline Honda GX120 & 2.64 & 2.82 & 450 & Gasoline & 310 \\
\hline Honda GX200 & 3.8 & 4.576 & 450 & Gasoline & 255 \\
\hline $\begin{array}{l}\text { Yanmar } \\
\text { L40AE-S }\end{array}$ & 2.7 & 3.1 & 450 & Diesel & 275 \\
\hline $\begin{array}{l}\text { Yanmar } \\
\text { L48AE-S }\end{array}$ & 2.86 & 3.5 & 450 & Diesel & 270 \\
\hline $\begin{array}{l}\text { Yanmar } \\
\text { L60AE-S }\end{array}$ & 3.7 & 4.5 & 450 & Diesel & 255 \\
\hline $\begin{array}{l}\text { Yanmar } \\
\text { L70AE-S }\end{array}$ & 4 & 5.2 & 450 & Diesel & 260 \\
\hline $\begin{array}{l}\text { Yanmar } \\
\text { NSB50 }\end{array}$ & 6.5 & 3.3 & 450 & Diesel & 280 \\
\hline $\begin{array}{l}\text { Yanmar } \\
\text { NSB75 }\end{array}$ & 9 & 4.4 & 450 & Diesel & 260 \\
\hline YanmarNSB11 & 10.5 & 6.9 & 450 & Diesel & 260 \\
\hline Honda EP5500 & 17 & 5 & 450 & Gasoline & 474 \\
\hline
\end{tabular}

Table 2. Values for fuel and exhaust gases flows.

\begin{tabular}{|l|l|l|l|l|}
\hline $\begin{array}{c}\text { Mass } \\
\text { flow of } \\
\text { fuel } \\
{[\mathrm{kg} / \mathrm{h}]}\end{array}$ & $\begin{array}{c}|c| \\
\text { gasoline } \\
{[\mathrm{kW}]}\end{array}$ & $\begin{array}{c}\eta_{\text {ge }}, \\
\text { gasoline }\end{array}$ & $\begin{array}{c}\mathrm{E}_{\text {fuel, }} \\
\text { biogas } \\
{[\mathrm{kW}]}\end{array}$ & $\begin{array}{c}\text { Mass flow } \\
\text { of exhaust } \\
\text { gases } \\
{[\mathrm{kg} / \mathrm{h}]}\end{array}$ \\
\hline 1.364 & 13.2069 & 0.332 & 20.3798 & 56.0725 \\
\hline 0.5456 & 5.2827 & 0.3332 & 8.1519 & 22.4290 \\
\hline 0.8742 & 8.4644 & 0.3332 & 13.0616 & 35.9373 \\
\hline 1.16688 & 11.2983 & 0.4050 & 21.1950 & 58.3154 \\
\hline 0.8525 & 9.0812 & 0.3414 & 14.3585 & 39.5056 \\
\hline 0.945 & 10.0665 & 0.3477 & 16.2112 & 44.6031 \\
\hline 1.1475 & 12.2237 & 0.3681 & 20.8430 & 57.3468 \\
\hline 1.352 & 14.4021 & 0.3611 & 24.0852 & 66.2674 \\
\hline 0.924 & 9.8428 & 0.3353 & 15.2849 & 42.0543 \\
\hline 1.144 & 12.1864 & 0.3611 & 20.3798 & 56.0725 \\
\hline 1.794 & 19.1105 & 0.3611 & 31.9592 & 87.9318 \\
\hline 2.368 & 39.079 & 0.1279 & 23.1589 & 51.77 \\
\hline
\end{tabular}

Figure 5. Filtration system. 
Table 3. Values for biogas flow.

\begin{tabular}{|l|l|l|l|l|l|l|}
\hline $\begin{array}{c}\text { Mass flow } \\
\text { of } \\
\text { air[kg/h] }\end{array}$ & $\mathrm{E}_{\mathrm{c}}[\mathrm{kW}]$ & $\begin{array}{c}\mathrm{E}_{\mathrm{w}} \\
{[\mathrm{kW}]}\end{array}$ & $\begin{array}{c}\eta_{\text {ge, }}, \\
\text { biogas }\end{array}$ & $\begin{array}{c}\eta_{\text {ge }}, \text { hot } \\
\text { water }\end{array}$ & $\begin{array}{c}\eta_{\text {global }}, \\
\text { biogas }\end{array}$ & $\begin{array}{c}\text { Mass } \\
\text { flow of } \\
\text { biogas } \\
\mathrm{kg} / \mathrm{h}]\end{array}$ \\
\hline 52.5679 & 3.7488 & 2.9990 & 0.3032 & 0.1081 & 0.4503 & 3.5045 \\
\hline 21.0272 & 1.4995 & 1.1996 & 0.3032 & 0.1081 & 0.4503 & 1.4018 \\
\hline 33.6913 & 2.4026 & 1.9221 & 0.3032 & 0.1081 & 0.4503 & 2.2461 \\
\hline 54.6706 & 3.8987 & 3.1190 & 0.3750 & 0.1081 & 0.5222 & 3.6447 \\
\hline 37.0365 & 2.6412 & 2.1129 & 0.3114 & 0.1081 & 0.4585 & 2.4691 \\
\hline 41.8154 & 2.9820 & 2.3856 & 0.3177 & 0.1081 & 0.4648 & 2.7877 \\
\hline 53.7626 & 3.8340 & 3.0672 & 0.3381 & 0.1081 & 0.4853 & 3.5842 \\
\hline 62.1257 & 4.4303 & 3.5443 & 0.3311 & 0.1081 & 0.4782 & 4.1417 \\
\hline 39.4259 & 2.8116 & 2.2493 & 0.3053 & 0.1081 & 0.4524 & 2.6284 \\
\hline 52.5679 & 3.7488 & 2.9990 & 0.3311 & 0.1081 & 0.4782 & 3.5045 \\
\hline 82.4361 & 5.8787 & 4.7030 & 0.3311 & 0.1081 & 0.4782 & 5.4957 \\
\hline 47.789 & 3.1292 & 2.5034 & 0.2159 & 0.1081 & 0.3240 & 3.9824 \\
\hline
\end{tabular}

Table 4. First biogas composition analysis.

\begin{tabular}{|l|c|c|}
\hline & Without filtration [\%] & With filtration [\%] \\
\hline $\mathrm{O}_{2}$ & 0.8 & 0.6 \\
\hline $\mathrm{N}_{2}$ & 2.4 & 2.0 \\
\hline $\mathrm{CO}_{2}$ & 40.0 & 34.4 \\
\hline $\mathrm{CH}_{4}$ & 54.0 & 61.8 \\
\hline $\mathrm{H}_{2} \mathrm{~S}$ & 2.8 & 1.2 \\
\hline
\end{tabular}

Table 5. Second biogas composition analysis.

\begin{tabular}{|l|c|c|}
\hline & Without filtration [\%] & With filtration [\%] \\
\hline $\mathrm{O}_{2}$ & 0.6 & 0.4 \\
\hline $\mathrm{N}_{2}$ & 2.4 & 2.0 \\
\hline $\mathrm{CO}_{2}$ & 40.0 & 34.4 \\
\hline $\mathrm{CH}_{4}$ & 54.0 & 61.8 \\
\hline $\mathrm{H}_{2} \mathrm{~S}$ & 3.0 & 1.4 \\
\hline
\end{tabular}

\section{DISCUSSION}

Small wastewater treatment station started about middle of 2007. It was inoculated with $12 \mathrm{~m} 3$ of a flocculent sludge from an anaerobic effluent treatment station of a local brewery. After that, several analyses were done for chemical demand of oxygen (CDO) and bio-chemical demand of oxygen (BDO), as showed in Tables 6 and 7 (Spinola, 2007).

Table 6. COD analysis.

\begin{tabular}{|c|c|c|c|c|}
\hline Date & $\begin{array}{c}\text { Anaerobic } \\
\text { System } \\
\text { Entrance } \\
{[\mathrm{mg} / \mathrm{L}]}\end{array}$ & $\begin{array}{c}\text { Anaerobic } \\
\text { System } \\
\text { Exit } \\
{[\mathrm{mg} / \mathrm{L}]}\end{array}$ & $\begin{array}{c}\text { Aerobic- } \\
\text { Anoxic } \\
\text { System } \\
\text { Exit } \\
{[\mathrm{mg} / \mathrm{L}]}\end{array}$ & $\begin{array}{c}\text { Total } \\
\text { Removal } \\
{[\%]}\end{array}$ \\
\hline $4 / 20 / 07$ & 177 & 105 & 72 & 59.00 \\
\hline $5 / 20 / 07$ & 260 & 111 & 75 & 71.10 \\
\hline $9 / 11 / 07$ & 518 & 239 & 83 & 83.97 \\
\hline
\end{tabular}

Table 7. BOD analysis.

\begin{tabular}{|c|c|c|c|c|}
\hline \multirow{4}{*}{ Date } & $\begin{array}{c}\text { Anaerobic } \\
\text { System } \\
\text { Entrance } \\
{[\mathrm{mg} / \mathrm{L}]}\end{array}$ & $\begin{array}{c}\text { Anaerobic } \\
\text { System } \\
\text { Exit } \\
{[\mathrm{mg} / \mathrm{L}]}\end{array}$ & $\begin{array}{c}\text { Aerobic- } \\
\text { Anoxic } \\
\text { System } \\
\text { Exit } \\
{[\mathrm{mg} / \mathrm{L}]}\end{array}$ & $\begin{array}{c}\text { Total } \\
\text { Removal } \\
{[\%]}\end{array}$ \\
\hline $9 / 11 / 07$ & 334 & 94 & 33 & 71.85 \\
\hline
\end{tabular}

\section{CONCLUSIONS}

This system initiated operations about February 2008 with a donated sludge from a brewery facility. $\mathrm{Up}$ to the present time, results are $83 \%$ of reduction for $\mathrm{CDO}, 72 \%$ of reduction for $\mathrm{BDO}$, and $33 \mathrm{mg} / \mathrm{L}$ of outcome BDO.

According to Brazilian environmental legislation a wastewater treatment plant should reduce at least $80 \%$ of $\mathrm{BDO}$ or its treated water should leave the system with less than $70 \mathrm{mg} / \mathrm{L}$ of BDO.

Comparing results obtained up to now with the minimum values demanded by Brazilian environmental legislation, they are considered satisfactory because only one digester was operational while the others were not operational for several reasons, such as little time of operation, low temperatures in most of the time, and low effluent volume.

\section{ACKNOWLEDGEMENTS}

We thank CNPq that provided the development of this work through a Scholarship.

\section{REFERENCES}

Beduschi, L. C., Lopes, L. R., Benincasa, M., Ortolani, A. F., and Lucas, Jr., J., 1983, Economic Viability of Methane Digesters, Engenharia Agricola, Vol. 6, No. 2, pp. 31-36. [In Portuguese]

Bohme, C., 2004, Calculations and Evaluations of a Biogas Testing Plant at the Sao Paulo State University at Guaratingueta, Report of Practical Internship $5 \mathrm{~V}$ Bachelor, Sao Paulo State University, Guaratingueta, SP.

Guardabassi, P., and Pires, R. G., 2006, Electric Power Self-generation in Residential Condominiums Using Waste Biogas and Natural Gas, in: Ferrer, J. T. V., editor, Biogas: Brazilian Projects and Researches, SMA. [In Portuguese]

Jordao, E. P. and Alem Sobrinho, P., 2004, Brazilian Research and Experiments with Posttreatment to UASB Reactors, in: PROSAB / FINEP Report, UFSCar. [In Portuguese]

Martins, O. S., Guardabassi, P., and Costa, D. F., 2006, Electric Power Generation from Biogas Produced in Waste Water Treatment: Pilot-project on Barueri WWTS, in: Ferrer, J. T. V., editor, Biogas: Brazilian Projects and Researches, SMA. [In Portuguese] 
Oliveira, S., 2001, Urban Solid Residues USR: Agronomy Course Class Notes, UNESP-FCA at Botucatu (Department of Natural Resources). [In Portuguese]

Oliveira, R. A., and Foresti, E., 2004, The Mass Balance of Upflow Anaerobic Sludge Blanket (UASB) from Swine Residual Waters Treatment, Engenharia Agricola, Vol. 24, No. 3, pp. 807-820. [In Portuguese]

Silveira, J. L., 1998, A Contribution for Thermoeconomic Modelling: Energy Systems Operation and Design Optimisation, Teaching Research on Thermodynamics, Sao Paulo State University, Guaratingueta, SP. [In Portuguese]

Spinola, F. G., 2007, Efficiency Evaluation of Low Cost System for Filtering and $\mathrm{H}_{2} \mathrm{~S}$ Discharge from Biogas, Report of FAPESP Scholarship, Sao Paulo State University, Guaratingueta, SP. [In Portuguese] 